DOI: 10.20472/IAC.2017.034.031

\author{
SHARON MASHAU \\ Southern Business School, South Africa
}

NICO SCHUTTE

GIFT Talent Research Niche Area North-West University, South Africa

\title{
EXPLORING THE ROLE OF CUSTOMER RELATIONS MANAGEMENT IN ENHANCING SERVICE DELIVERY BETWEEN SUPPORT STAFF AND STUDENTS IN A SELECTED HIGHER EDUCATION INSTITUTION
}

\begin{abstract}
:
The main objective of this research was to determine the role of customer relationship management in enhancing the service delivery between support staff and students in a selected higher education institution. A qualitative research approach was followed with semi-structured interviews done with students and support staff from a selected South African higher education institution $(N=8)$. The participants in the study felt that the current level of service delivery by the institution does not necessarily exceed their expectations. The findings further showed that higher education institutions should determine the needs of students and provide the best service possible to keep them satisfied. Recommendations are made.
\end{abstract}

\section{Keywords:}

Academics, Customer Relationship Management, Higher Education, Service Delivery, Students

JEL Classification: J24 


\section{Introduction}

The recruitment and retention of students have been moved to the top of most universities' priorities to increase the South African educated population in line with government targets. The South African government plans to raise university enrolments from 983698 in 2013 to 1.5 million by 2030. The Green Paper on Post-School Education and Training (2012), from the Department of Higher Education and Training (DHET), sets a comprehensive agenda for post-school education in the coming two decades, including new funding, access and redress policies for universities.

Student satisfaction is of paramount importance in an area of increased competition and decreased government subsidies. As mentioned by Dominic and Guzzo (2010) and Berkowitz (2006) the provision of good quality services and the satisfaction of customers are critical points in the growth, development and sustainable performance of higher education institutions. Unfortunately customer orientation has been underemphasized in colleges and universities (Fontaine, 2014). As a result higher education are facing significant challenges to attract and retain their students. This requires from higher educational management to adopt a more customer-oriented philosophy towards their students. As mentioned by Hejwosz (2010) higher education have become a commercialized venture where all the stakeholders are seen as revenue centres, every student as a customer and every professor as an entrepreneur. Le Roux and van Rensburg (2014) maintain that satisfied undergraduate students remain loyal to their institutions and are likely to complete their studies.

The aim of this study was to explore the role of customer relationship management (CRM) in enhancing service delivery between staff and students in a selected higher education institution. More specifically the research aimed to answer the following research questions:

- What role does customer relationship management play in the higher education institution from support staff perspective?

- What role does customer relationship management play in the higher education institution from the students' perspective?

- To what extent does customer relationship management enhance service delivery between support staff and students in the higher education institution?

\section{Literature Review \\ Defining Customer Relationship Management}

According to Gholamia, Samanb, Sharifc and Zakuand (2015) customer relationship management is a strategy for aligning business practices with customer requirements to create stronger relationships. CRM systems enable customers to interact with the business on an individualised, need-specific manner, and include processes to bring together information about both the customer and the business (Seeman \& O'Hara, 2006). The ability to access and analyse all customer interactions and collate the 
information is essential to provide the high quality of services that today's customers demand (Sundar, Murthy, Yadapadithaya, 2012). The availability of customer information enables employees to make appropriate decisions to meet customer needs (Teo, Devadoss \& Pan, 2006).

Adhikari and Adhikari (2009) highlights the following key principles for developing and maintaining a healthy customer relationship:

- A willingness from both the organization and the customer to stay committed to the relationship which is based on mutual benefits.

- A 'non-transactional' orientation that involves a combination of strategies which build up the relationship between the organization and the customer over a period of time.

- A willingness from the organization to invest in an infrastructure that can assist in the implementation of the CRM system.

\section{Applying Customer Relationship Management in Higher education institutions}

According to Wahab (2016) education service providers are grappling with increasing competition as new institutions are established (both public and private), that offers similar programmes with more state of the art content delivery methods such as distance and e-learning. Although public higher education institutions spend a substantial amount of funds to recruit students into academic programmes, the retention rates of these students remain low (Crosling, Heagney \& Thomas, 2009). There are some evidence to suggest that higher education institution do not spend sufficient time on developing programmes to increase students' satisfaction (D'Costa \& Colaco, 2014; Fozia, Shiamwama, Otiso, 2014).

According to George, Emmanuel and Christiana (2012) customer satisfaction is the core of every business philosophy and should focus on the creation of worth for customers, forestalling and managing customers' expectations, and signifying capacity and responsibility that will satisfy customers' needs. Ricky (2012) in particular observed that the service standard provided to students is important and that institutional officials should observe the following when providing services to students:

- Students should be treated with dignity and respect.

- Students should be given clear directions on how to handle specific issues.

- School officials should be responsive to students' and parents' concerns.

- Students' grievances should be attended to promptly.

Adikaram, Khatibi, DotaWiri and Yajid (2016) point out that there are different expectations that students have from their respective institutions. Students require amongst others continuous communication relevant to lecture schedules, academic work flow, degree completion plan, examination mechanisms; and programme delivery structures with assessment criteria, standards of the faculty/lecturers, infrastructure facilities, and examination standards. Fontaine (2014) furthermore points out that new 
millennium students are good at comparison shopping - they'll see which college has the best technology, the best buildings, and the best on-campus eateries (those eateries need to reach beyond the campus-managed cafeteria). Combined the effectiveness to which higher education institution execute the above practices will have a significant impact on its ability to attract and retain students.

\section{Research Design}

\section{Research approach}

A qualitative research approach using semi-structured interviews based on the CRM perspectives and relationships between the support staff and students was used. The goal for this approach was to explore and understand the phenomenon of customer relationship management in enhancing service delivery. According to Khan (2014), qualitative research is an inquiry process of understanding based on distinct methodological traditions on inquiry that explore a social or human problem. The researcher builds a complex, holistic picture, analyses words, reports details of informants, and conducts the study in a natural setting. Qualitative research is based upon the observations and interpretations of people's perceptions of different events and it takes a snapshot of the people's perceptions in a natural setting. A case study strategy was applied for this research using a selected South African Higher Education Institution as the case study. More specifically, the case study was made up of two cases, namely: support staff and students. The themes were derived from the semistructured interviews and were compared with relevant literature to generate a universal result. Eight participants were interviewed.

\section{Sampling}

Sampling involves taking a representative selection of the population and using the data collected as research information. It is a "subgroup of a population" (Latham, 2007). The sampling method that was adopted by the researcher is probability sampling using stratified sampling method. This assisted the researcher to separate the population into two subgroups (stratas) for cost efficiency and to reduce sample errors. The units of analysis for this study were drawn from four support staff (strata 1) and four students (strata 2) within the University of Venda, representing different levels of study.

Table 1: Demographic Characteristics of the participants

\begin{tabular}{|l|l|l|l|l|}
\hline Participant & Age & Gender & $\begin{array}{l}\text { Highest } \\
\text { Qualification }\end{array}$ & $\begin{array}{l}\text { Years of } \\
\text { engagement/ } \\
\text { service with } \\
\text { the HEI }\end{array}$ \\
\hline Staff Members & Older than 40 & Female & Honours & 5 and more \\
\hline 1 &
\end{tabular}




\begin{tabular}{|c|c|c|c|c|}
\hline 2 & Older than 40 & Male & Bachelors & 3 to 5 \\
\hline 3 & $35-40$ & Male & Honours & 5 and more \\
\hline 4 & $30-35$ & Female & Honours & 2 to 3 \\
\hline \multicolumn{5}{|c|}{ Students } \\
\hline 5 & $25-30$ & Female & $\begin{array}{l}\text { Enrolled for } \\
\text { undergraduate }\end{array}$ & 3 to 5 \\
\hline 6 & $25-30$ & Male & Bachelors & 2 to 3 \\
\hline 7 & $25-30$ & Female & Bachelors & 3 to 5 \\
\hline 8 & $25-30$ & Male & Bachelors & 3 to 5 \\
\hline
\end{tabular}

\section{Data collection methods}

Data were collected through face to face semi-structured interviews with selected participants. Semi-structured interviews are often the sole data source for a qualitative research project and are usually scheduled in advance at a designated time and location outside of everyday events. They are generally organised around a set of predetermined open-ended questions, with other questions emerging from the dialogue between interviewer and interviewees. Semi-structured interviews are the most widely used interviewing format for qualitative research and can be administered either with an individual or in groups (DiCicco-Bloom \& Crabtree, 2006).

\section{Data Analyses}

Qualitative content analysis is the analysis strategy of choice in this qualitative descriptive study. It allowed the researcher to test theoretical issues to enhance understanding of the data. The section provides and describes how data was analysed. For this research, theme (content) analysis was applied to analyse and interpret the data. Collected data were prepared thereafter, the data were thoroughly analysed to identify theme (content) and subthemes.

Table 2 provides a summative overview of the responses by a combination of similar responses in terms of positive $(+)$, negative $(-)$ response and positive response with element of negative $+(-)$. 
Table 2: Combination of Similar responses by Themes and Sub-themes

\begin{tabular}{|c|c|c|c|}
\hline Themes and Sub-themes & $\begin{array}{l}\text { Positive } \\
\text { response }\end{array}$ & $\begin{array}{l}\text { Negative } \\
\text { responses }\end{array}$ & $\begin{array}{c}\text { Positive with } \\
\text { elements of } \\
\text { negative }\end{array}$ \\
\hline \multicolumn{4}{|l|}{ The role of CRM from Support Staff perspective } \\
\hline Students' needs and providing satisfactory service & 4 & 0 & 0 \\
\hline $\begin{array}{l}\text { Efficiency in using internal systems to enhance service } \\
\text { delivery }\end{array}$ & 3 & 1 & 0 \\
\hline Understanding about student perception & 3 & 1 & \\
\hline Student retention and referrals & 4 & 0 & 0 \\
\hline \multicolumn{4}{|l|}{ The role of CRM from Student perspective } \\
\hline Responsiveness to student concerns & 1 & 1 & 2 \\
\hline Treatment of students with dignity and respect & 2 & 0 & 2 \\
\hline Willingness from support staff to help with prompt service & 3 & 1 & 0 \\
\hline \multicolumn{4}{|l|}{$\begin{array}{l}\text { The extent to which CRM enhances service delivery } \\
\text { between support staff and students }\end{array}$} \\
\hline $\begin{array}{l}\text { Willingness from both the staff and student to stay } \\
\text { committed to the relationship }\end{array}$ & 7 & 0 & 1 \\
\hline Willingness of management to invest in infrastructure & 6 & 2 & 0 \\
\hline Availability of appropriate infrastructure and resources & 3 & 3 & 2 \\
\hline
\end{tabular}

\section{Theme 1: The role of CRM from Support Staff}

\section{Sub-theme 1: Students' needs and providing satisfactory service}

Respondents 1 and 3 are of the view that students are important clients and should be handled with care and be provided with clear and correct information. On the other hand, respondent 2 and 4 indicated that the best service to students is provided once the students' needs are identified.

Respondent 1 indicated that understanding students' needs and providing satisfactory service means:

“... Giving them clear and correct information when they enquire, alerting them about financial assistance opportunities and also work experience". 
Respondent 3 is of the view that:

"... A student is an important client of the university and therefore should be handled with care. They should be given excellent service at all times".

Respondent 2 in agreement stated that:

“... Students have various needs such as money for tuition fees, books and accommodation. Satisfactory service can only be provided to students once their needs are identified".

Respondent 4 stated that:

"...The University's core function is to provide learning and teaching to students, therefore, it is survived by students, hence students must receive the best service in order to keep them satisfied".

\section{Sub-theme 2: Staff effectiveness in using internal systems to enhance service delivery}

Respondents 2 and 3 provided similar responses and indicated how effective the internal system is in enhancing service delivery to students based on how they access and what they do with student data. Respondent 3 relies on other departments to provide student information which is accessed from internal systems in order to assist the respondent when working on matters that concern university students. Respondent 4 , however is of the view that internal systems are not geared to enhance service delivery.

Respondent 2 indicated that:

“...My role includes fundraising for needy students and those who are meritorious in performance. Student data which is updated helps me to know the number of students who need financial assistance and as such, it further gives me an idea of how much I should fundraise".

Respondent 3 stated that:

“...University administrators play a vital role in the revision of student data (internal system) as they are the mirror of the University. This indicates the essence of ensuring efficiency and effectiveness of using internal systems to enhance service delivery". 
Respondent 4 however is of the view that:

"...Currently, there are no proper internal systems to review student data in terms of service delivery. However, students can escalate unresolved problems to senior management. The University has different systems for different functions, however, I don't think they are aligned to satisfy student perse".

\section{Sub-theme 3: Understanding on student perception of service}

While 3 of the respondents believe that student are like customers, want quick service that will help them with their studies. Respondent 1 is of a different view and highlights issues of corruption and nepotism.

Respondent 1 indicated the following about the students:

"...They think there is nepotism and corruption with regards to allocation of bursaries and hiring interns".

On the other hand, respondent 2 stated that:

“...Students perceive service as work which employees do to help them study well without hindrances, and they expect us to do more for them".

Respondent 3 agrees by stating that:

"...Students are like customers who think a customer is always right. That is why they always demand quality and good service".

Respondent 4 confirms the above by stating that:

"...Students want quick service and they want service to be at their best interest. Students feel that all resolutions must be to their best interest".

\section{Sub-theme 4: Student retention and referrals}

All four respondents provided different views in terms of student retentions and student referrals and their different perspectives were dependent on the offices they held. 
Respondent 1 states that:

"...the University is competing with many universities around the country, so retention will depend on the quality of infrastructure which is conducive to learning and offered programmes.

On the other hand, respondent 3 articulates that:

"...Student retention is the process of ensuring that students get excellent service and keeping then at the university instead of losing them to other competitive universities. Student referrals is the process of referring students to offices /staff where they are certain they will get help".

Respondent 2 is of the view that:

"...There is retaining of students and ensuring that they only leave the system after graduating. On average, there is 3\%-4\% of students who drop out because of financial difficulties. Students' referrals on the other hand seem to be high to a point where a student can be referred to different Schools or departments for assistance in their choice of study".

Respondent 4 states that:

"...The University has managed to recruit students from various parts of the world using various strategies. This is visible from the high number of applications we receive each year. The university produces referral graduates every year".

\section{Theme 2: The role of CRM from Student perspective}

\section{Sub-theme 1: Responsiveness to student concerns}

Respondent 5 and 7 provided positive responses with an element of negative view, whereas respondents 6 and 8 gave a definite positive and a definite negative answer respectively.

Respondent 5 indicated that:

"...Yes, they are very responsive when we ask for their help regarding their field of expertise, but some can be rude at times, 'you are merely asking a simple question!"”. 
Respondent 7 on the other hand stated that:

"...They sometimes respond to my concerns in a good way and I am able to get help very fast. However, here at the institution, there are those who don't respond to my concerns in a good manner. E.g. at SRA (Housing), they just take me from pillar to post without any solution to my problem".

Respondent 6 stated that:

“...Staff's responsiveness towards students' concerns is very poor because for one, you can end up concluding that the management is much damaged. Staff forget that their duty is to help students than to be stiff and give us attitudes wherever we need help".

On the other hand respondent 8 indicted that:

"...It is very timely and the staff engage critically with us on issues which concern us and affect us; especially academic concerns".

\section{Sub-theme 2: Treatment of students with dignity and respect}

Respondents 5 and 6 are of the view that students are treated with dignity and respect but also have some negative reservations. On the other hand, both respondent 7 and 8 believe that students are treated with dignity and respect.

Respondent 5 commented that:

"...Most of them do, but enjoy being bossy or showing you that they have authority".

Respondent 6 further indicated a similar view by stating that:

"...Some staff do treat students with dignity and respect while some do not. Staff tend to put much focus on helping those they know or their friends and family members while the disadvantaged students who are not known do not get help. So they are not respecting us".

Respondent 7 stated that:

"...They treat me with respect and dignity. What I know about them is that if you show then the respect they also treat you with respect and dignity. I have seen that in the new Student Administration Building". 
Respondent 8 in agreement indicated that:

"...They are respectful, gentle and welcoming. They treat students with respect and kindness".

\section{Sub-theme 3: Willingness from support staff to help with prompt service}

Respondents 5, 7 and 8 were in agreement that the support staff showed willingness to help them with prompt service as an when they engage with then. On the other hand, respondent 6 does not agree and provided a different point of view.

Respondent 5 stated that:

"...Most of the people I have requested help from have been willing to assist me without looking at positions they hold in the office".

Respondent 7 agrees and says:

"...Yes, they are able to help me immediately when I tell them my concerns. I remember the time when I was stressed and my results were blocked, I called at the Old Administration Building and within 5 minutes my results where unblocked".

Respondent 8 also is of the view that:

"...They are ready to help at all times, they use open door policy, and their offices are easily accessible".

In contrast Respondent 6 indicates that:

"...It's not all the times wherein the staff is willing to help you because sometimes you get to be sent back and forth or spend the whole week coming to get assisted for one simple thing, example getting signatures from HoDs". 


\section{Theme 3:}

The extent to which CRM enhances service delivery between support staff and students

\section{Sub-theme 1: Willingness from both the staff and students to stay committed to the relationship}

The findings shows that almost all the respondents except for respondent 3 agree that there is a willingness from both staff and students to stay committed to the relationship.

Respondent 1 indicated that:

"...There is commitment since we have internships that we administer and they have good relationship to the office. They also respond positively to our requests (both interns and mentors)"

Respondent 2 indicated that:

"...Maturity between the two groups is good as students on personal and professional levels get assistance. Professional in the sense that there are students who would run short of some of their needs, some of the staff will assist the student concerned".

Respondent 4 alluded that:

"...Staff are willing to assist each other as well as assist students"

In agreement respondent 5's response was:

"...l strongly believe that both staff and students are prepared to be committed if they see how valuable their relationships are".

Respondent 8 further agreed and stated that:

"...Both parties participate honestly to maintain a mutual beneficial relationship and achieve pre-determined goals".

In addition to the above responses, respondent 7 stated that:

"...They should respect each other and always listen to each other's opinion so that they should maintain a good relationship. Both staff and students 
should know the main reason as to why they are here at the university, they should know their duties".

Respondent 6 is of the opinion that:

"...Customer relationship does enhance so much the service delivery because if the staff show interest in helping the students, after all it is their duties to help students, it will make us not to have a negative attitude towards the management or the staff. I think they are willing to stay committed to the relationship"

On the other hand, however, respondent 3 shares that:

"...staff is willing only when there is something they get in return and students get committed only to those who show good customer skills".

Respondent 3 stated that:

"...the staff will always be willing to assist students as long as their services are rewarded accordingly, i.e. increased benefits, uplift morale and increased service and productivity. Students on the other hand always prefer to get assistance from staff with good customer relations".

\section{Sub-Theme 2: Willingness of management to invest in infrastructure}

Respondent 2, 5, 7 and 8 agreed that there is a willingness from management to invest in infrastructure, whereas respondents 3 and 6 believe that there is still need to invest more in all possible infrastructure.

Respondent 2 provides that:

"...recently, we have new buildings, refurbishment of the existing infrastructure, access to Wi-Fi increased to full service on campus and the rollout of tablets to all registered students also make it easy for them to work on their studies".

Respondent 5 also states that:

"...looking at how our University was in the past 5 years, I would strongly agree that the management is willing to invest. Even our website has improved very well". 
In agreement, respondent 7 stated that:

"...There is a willingness from the University management to invest in infrastructure for example, they have brought Wi-Fi of which all students are able to do their assignments and research. This results in students achieving high marks and as such, the University is able to achieve its goal"

Respondent 8 alluded that:

"...there is, they continuously update my access for easy access and use and have also simplified the library data bases".

Although there is willingness from management to invest in infrastructure, respondent 3 indicated that:

"...Based on my experience in the university, there is willingness from management to invest in such infrastructure. For example there has been a very bust improvement of using ITS system. There is still a need to invest in all possible infrastructure to enhance infrastructure and customer relations management systems of the university".

This was supported by respondent 6 who also indicted that:

"...The willingness is there but the University management is still too focused on improving the building infrastructure of the university. If they implement more of the web-based systems it will bring an advanced improvement".

Respondents 1 and 4 are of the view that university management might not see the need to invest in CRM because they are not operational, but if the idea is brought to their attention, they will support it.

Respondent 1 indicated that:

"...Providing quality service is first priority to any employer. I am sure if the idea of investing in customer service is brought to their attention they will support it".

Respondent 4 agreed by stating that: 
"...University management is not at the field level, hence might not see the importance for a CRM. Management is comprised of older age group who are rather old-fashioned and not technologically advanced".

\section{Sub-Theme 3: Availability of appropriate infrastructure and resources}

The findings shows that respondents 2 and 7 are of the view that the University have an appropriate infrastructure and resources to enhance service delivery to all its stakeholders, whereas respondents 1,6 and 8 indicated that there is shortage of accommodation and office space, long queue for registration and improper IT services, and lack of recent resources from the library.

Respondent 2 stated that:

"...To a large extent yes, the institution has the infrastructural resources to ensure that it serves its stakeholders better".

To support this, respondent 7 indicated that:

"...as students we find that we have venues to attend our classes, lectures have their respective offices, cleaners have different cleaning equipment to use, etc."

A different view is however, echoed from respondent 1 who stated that:

“...The University is still lagging behind. For example, we don't have enough accommodation and lecture halls for students as well as accommodation and offices for employees".

This is supported by respondent 8 who alluded that:

“...theatres are not enough. Some are old and not really conducive for learning. Recent information is not readily found in the library, it is only old books".

In addition, respondent 6 who agrees by indicating that:

"...We still have to queue for registration, to get student cards and to add and cancel modules. Everything is a queue. If they make or invest on their IT services, we won't have much of unwillingness of staff to help students". 
On the other hand respondents 3,4 and 5 alludes that to some extent, there is availability of appropriate infrastructure and resources, but more could be done to improve the current stand point. These respondents are of the view that the university still lags behind when compared to other universities.

Respondent 3 indicated that:

"...To some extent, but it is not there yet compared to other universities. There is a need to invest more on infrastructure, more especially in this day of technology".

In agreement, respondent 4 stated that:

"...It still feels there could be more to do in improving our current stand point".

Respondent 5 further indicted that:

“...The University has appropriate infrastructure and resources to enable service delivery to stakeholders, however, some areas might require training, motivation and effective implementation".

\section{Discussion}

The main objective of this research was to determine the role of customer relationship management in enhancing the service delivery between support staff and students in a selected higher education institution. The participants in the study felt that the current level of service delivery by the institution does not necessarily exceed their expectations. The findings further showed that higher education institutions should determine the needs of students and provide the best service possible to keep them satisfied. The findings support the recommendations of D'Costa and Colaco (2014) who maintained that higher education institutions should understand student's needs in order to provide satisfactory service.

The research findings reveal that students perceive service as work that support staff do to help them with their studies. Just like any other customer out there, students want quick service, they demand quality and good service, they believe they are always right, and they strongly feel that all resolutions should be to their best interest. This means that the support staff know what students require and this makes it easier to provide them with exceptionally good quality service. In line with Fozia, Shiamwama and Otiso (2014) it is evident that higher education students are demanding more attention and immediate service. Higher education institutions therefore need to be proactive and be able to adjust their practices by refocusing their efforts externally on the student market. 
The research findings indicate that there is a different sense with regard to staff's responsiveness to students' concerns. Not all students are treated similarly in terms of responding and addressing their concerns. Some embrace the treatment they get when they encounter support staff and other students feel that the experience is a daunting one. This shows that there is a lack of consistency in terms of service delivered to students. What has also been found is that the university has no mechanisms in place to address lack of responsiveness to students' concerns and in many occasions, this leads to student protests.

Clearly there are basic principles about the customer service paradigm that could and should be utilized in higher institutions of learning. Ricky (2012) observed that the service standard provided to students is important. Ricky (2012) further opines that institutional officials need to ensure that student are treated with dignity and respect, but the university still experiences challenges in this area.

The findings indicate that to a large extent, there is a willingness for both support staff and students to stay committed in the relationship for as long as there is still mutual benefit. Students feel that the staff are willing to assist them for as long as they also maintain their respect in communicating with them and on the other hand; the support staff in support to the students feel that maturity and professionalism is also key in ensuring that students are assisted in a good and welcoming manner. The findings also revealed that from the support staff perspective, the willingness to stay committed to mutually beneficial relationship with students also lies in the support staff's happiness and contentment with their job with regard to increased benefits and uplifting staff morale. This in turn, increase service delivery to students and increase productivity.

The findings, however, also revealed that not all support staff and students are willing to commit to this mutual beneficial relationship. There is a feeling that there are some support staff members who portray a "superior mentality" when assisting students. The students tend to seek assistance from employees whom they perceive to be portraying good customer relations and who show willingness when engaging with them. The interaction between students and support staff is at times, a daunting experience to both the stakeholders.

Treating students as partners is crucial to optimize students' experience from enrolment to graduation. In this process, a person-to-person relationship between students and universities/colleges is of extreme importance for better planning and implementation. It is the quality of the experience and relationship that benefits both a higher education institution and its society (Fontaine, 2014). In developing better customer relationship, there should be a willingness from both the university and the students to stay committed to the relationship which is based on mutual benefit (Adhikari \& Adhikari, 2009). 
This research makes important theoretical and practical contributions. From a theoretical point of view this research contributes to the scarcity of empirical knowledge on customer relationship management and service quality among students in the higher educational context. From a practical perspective this research highlights important areas on which the higher education can improve to deliver effective services to students. The findings of this research recommend the development of a customer relationship model that can proactively detect the needs and requirements of a new generation students. The developed CRM model should be measured, monitored, and evaluated accordingly to ensure that it delivers its intended outcomes, which is, enhancing service delivery for students.

This research had some limitations. First a qualitative research approach was followed with a sample of participants from one higher education institution. The results of the study can therefore not be generalised. For future research it is recommended that the sample be expanded to include other stakeholders of the higher education institution such as management and academics staff to obtain a more holistic perspective on service delivery. This research can also be expanded to other higher education institutions to obtain local perspective on quality service delivery within higher education institutions.

In conclusion, changing student demands require from higher education institutions to deliver state of the art services. Higher educational management therefore need to adopt a customer relationship management approach to manage the student life-cycle effectively from start to finish. This will result in a higher attrition and retention rate of students and a more educated nation to cater for the societal and economic needs of a third world country such as South Africa.

\section{References}

ADHIKKARI, B., and ADHIKARI, B. 2009. Managing Customer Relationships in Service Organizations. Administration and Management Review. 2009, Vol. 21, No. 2, s. 65-78.

BERKOWITZ, Z., 2006. Customer Relationship Management. 8 Common goals for a CRM

Program. What are Key Drivers of Customer Satisfaction? Retrieved from http://onlinesuccesscentre.com. Reprint 2006.

CROSLING, G.; HEAGNEY, M., and THOMAS, L. 2009. Improving student retention in higher education: Improving Teaching and Learning. Australian Universities' Review. 2009, Vol. 51, No. 2, s. 9-18.

D'COSTA, A., A and COLACO, F., X. 2014. Customer Relationship Management and its Strategic Application in Different Businesses. IRC'S International Journal of Multidisciplinary Research in Social \& Management Sciences. 2014, Vol. 2, No. 3, s. 36-39.

Department of Higher Education and Training (2012). Green Paper for Post-School Education and Training 2012. Council for Higher Education. South Africa. Available from:

http://www.che.ac.za/sites/default/files/publications/DHET_green_paper_post_school_education_trainin g.pdf. Reprint 2012.

DICICCO-BLOOM B., and CRABTREE, B.F. 2006. Making sense of qualitative research: The qualitative research interview. Medical Education. 2006, Vol. 40, s. 321-314. 
DOMINICI, G., and GUZZO, R. 2010. Customer Satisfaction in the hotel Industry-A case study of Sicily. International Journal of Marketing Studies. 2010, Vol. 2, No. 2, s. 3-12.

FONTAINE, M. 2014. Student Relationship Management (SRM) in Higher Education: Addressing the Expectations of an Ever Evolving Demographic and Its Impact on Retention. Journal of Education and Human Development. 2014, Vol. 3, No. 2, s. 105-119.

FOZIA, R.N.; SHIAMWAMA, S.M., and OTISO, K.N. 2014. Impact of Customer Relationship Management as a Strategy for Competitive Advantage in Kenyan Public Universities: A Case Study of Moi University. International Journal of Business, Humanities and Technology. 2014, Vol. 4, No. 4, s. 37-145.

GEORGE, K. A.; EMMANUEL, A., and RACHEL, K. 2012. The impact of effective customer relationship management (CRM) on repurchase: A case study of Golden Tulip Hotel Accra-Ghana. African Journal of Marketing Management. 2012, Vol. 4, No. 1, s. 17-29.

GHOLAMIA, H.; SAMANB, M.S.M.; SHARIFC, S. and ZAKUAND, N. 2015. A CRM strategic leadership towards sustainable development in student relationship management: SD in higher education. Elsevier B.V: Procedia Manufacturing, 2015, Vol. 2, s. 51-60.

HEJWOSZ, D. 2010. Students as consumers: The commercialisation of higher education in the United States of America. Published on 31 May in Society. Liberté World Edition. Available from: http://liberteworld.com/2010/05/31/students-as-consumers-the-commercialisation-of-highereducation-in-the-united-states-of-america. Reprint 2010.

KHAN, S.N. 2014. Qualitative Research Method: Ground Theory. International Journal of Business and Management. 2014, Vol. 9, No. 11, s. 224-233.

LATHAM, B., 2007. Sampling: What is it? Qualitative Research Methods. ENG5377.

LE ROUX, A. and VAN RENSBURG, R.J. 2014. Student perceptions of customer experience in a higher education environment. Acta Commercii. 2014, Vol. 14, No. 1, s. 1-9

RICKY, L.B. 2012. Customer service in higher education: Finding a middle ground. The mentor, an academic advising magazine. USA: University of South Carolina. Reprint 2012.

SEEMAN, E.D. and O'HARA, M. 2006. Customer relationship management in higher education. CampusWide Information Systems, Vol. 23, No. 1, s. $24-34$

SUNDAR, P.K.; MURTHY, H.N, and YADAPADITHAYA, P.S. 2012. CRM Success Factors in Software Services firm: A Case Study Analysis. Information and Knowledge Management, 2012, Vol. 2, No. 8, s. 33-37.

TEO, T.S.H.; DEVADOSS, P., and PAN, S.L. 2006. Towards a holistic perspective of customer relationship management (CRM) implementation: A case study of the Housing and Development Board, Singapore. Decision Support Systems. 2006, Vol. 42, s. 1613-1627.

WAHAB, S. 2016. The implication of customer service in higher education: review paper. International Journal of Education and Practice. 2016, Vol. 4, No. 3, s. 106-111. 
